\title{
UNIVERSITYOF BIRMINGHAM

\section{Determinants influencing CSR practices in small and medium sized MNE subsidiaries: A stakeholder perspective}

\author{
Park, Byung II; Ghauri, Pervez N.
}

DOI:

10.1016/j.jwb.2014.04.007

License:

Creative Commons: Attribution-NonCommercial-NoDerivs (CC BY-NC-ND)

\section{Document Version}

Peer reviewed version

Citation for published version (Harvard):

Park, BI \& Ghauri, PN 2015, 'Determinants influencing CSR practices in small and medium sized MNE subsidiaries: A stakeholder perspective', Journal of World Business, vol. 50, no. 1, pp. 192-204.

https://doi.org/10.1016/j.jwb.2014.04.007

Link to publication on Research at Birmingham portal

\section{General rights}

Unless a licence is specified above, all rights (including copyright and moral rights) in this document are retained by the authors and/or the copyright holders. The express permission of the copyright holder must be obtained for any use of this material other than for purposes permitted by law.

- Users may freely distribute the URL that is used to identify this publication.

- Users may download and/or print one copy of the publication from the University of Birmingham research portal for the purpose of private study or non-commercial research.

- User may use extracts from the document in line with the concept of 'fair dealing' under the Copyright, Designs and Patents Act 1988 (?)

- Users may not further distribute the material nor use it for the purposes of commercial gain.

Where a licence is displayed above, please note the terms and conditions of the licence govern your use of this document.

When citing, please reference the published version.

Take down policy

While the University of Birmingham exercises care and attention in making items available there are rare occasions when an item has been uploaded in error or has been deemed to be commercially or otherwise sensitive.

If you believe that this is the case for this document, please contact UBIRA@lists.bham.ac.uk providing details and we will remove access to the work immediately and investigate. 


\title{
Determinants of CSR practices in small and medium sized MNE subsidiaries: A stakeholder perspective
}

\begin{abstract}
This research attempts to investigate key drivers motivating corporate social responsibility (CSR) practices by small and medium sized foreign subsidiaries. By using stakeholder theory and regression analysis, we integrate international business and CSR literature to suggest a research model and identify the factors functioning as catalysts in influencing CSR in local markets. We find that consumers, internal managers and employees', competitors and non-governmental organizations are primary determinants considerably influencing corporate citizenship behavior particularly in emerging markets. We also believe that our model contributes to current knowledge by filling several research gaps, and our findings offer useful and practical implications not only for local governments but also for multinational enterprises.
\end{abstract}

Keywords: Multinational enterprises, Corporate social responsibility, Stakeholder, Korea 


\section{Determinants of CSR practices in small and medium sized MNE subsidiaries: A stakeholder perspective}

\section{Introduction}

As globalization continues to increase in intensity, noticeable changes are taking place around the globe and a new understanding that international operations and investments are efficient means for firms to be competitive (Buckley \& Ghauri, 2004). Due to this fact, the outward stock value of FDI transactions grew from US\$523.9 billion a year in 1980 to US\$1.7 trillion in 1990 and US\$6.0 trillion in 2000 . The record figure for 2010 revealed an amount that more than tripled the year 2000 figure as worldwide FDI activities totalled US\$20.4 trillion (UNCTAD, 2001; 2011). Meanwhile, a wave of FDI has not only been sweeping through traditional advanced economies, but developing and emerging economies have been part of the surge, resulting in the enlargement of multinational enterprises (MNEs).

Another important international issue, coupled with the growth in the number and size of MNEs, has recently come to the forefront. As a recent phenomenon, MNEs have become aware that their mission should go beyond mere profit generation and their continued success in foreign markets is in part affected by organizational ethical standards (Tixier, 2003). In other words, although they basically seek to maximize their earnings abroad, firms are increasingly acknowledging the value of corporate social responsibility (CSR) and treating CSR as a strategic tool where the potential corporate benefits hinge on the communication of corporate responsibility (Polonsky \& Jevons, 2009).

Furthermore, some proponents of CSR argue that CSR leads to enhanced brand image and reputation, increased sales and customer loyalty, and increased productivity 
and quality (Mishra \& Suar, 2010). Consequently, CSR has often brought about an improvement in corporate financial performance (Mittal, Sinha, \& Singh, 2008). According to Luo (2006), CSR in the MNE context means the firm's configuration of social responsibility and social responsiveness, policies, and programs which can promote its relationship with local society. He also suggests that the concept of CSR assumes business and society are interwoven rather than being distinct entities. Thus, society has certain expectations as to what are adequate business attitudes and behaviors. Apart from MNEs instincts for profit-making, we argue that satisfaction of the local society's expectations is particularly crucial for MNEs as it is hard to deny the existence of skeptical opinions which portray MNEs as exploiters of host countries' resources, especially in developing and emerging countries. In this vein, CSR is not only important as a strategy, but also signifies an organizational task that MNEs should meet ethical, social, environmental, and economic demands from local stakeholders in host economies ${ }^{1}$.

With respect to the strategic implications of CSR for MNEs, there are numerous unanswered theoretical and empirical issues. One of the fundamental but prominent topics that needs to be immediately resolved is the identification of the motivations for CSR in MNE subsidiaries (Rodriguez, Siegel, Hillman, \& Eden, 2006). The links

\footnotetext{
${ }^{1}$ Some scholars (e.g., Chang, 2004; Ziegler, 2005) have shed light on the negative aspects of MNE operations, and even argue that MNEs are one of the primary obstacles inhibiting economic growth in developing and emerging countries. The explanations given by these scholars, proposing negative impacts are the following; often MNE activities are too vitalized and excessive, foreign firms attempt to dominate the market they enter and present a challenge to national sovereignty. Moreover, the aggravation of local competition against MNEs inevitably culls locally grown enterprises, which results in the deterioration of employment. In particular, MNEs re-invest only a fraction of their revenues in local economies and drain positive effects from both capital injections and the balance of payments. These negative effects cause hardships for local governments and negatively influence their investments in infrastructure, education and technology development. In this vein, we suggest that CSR is not only important for domestic firms but also should be considered as a crucial international issue in that CSR is an efficient means to overcome skeptical attitudes toward FDI in host markets. This discussion also explains the supporting rationale why MNE CSR needs to be particularly geared toward host economies.
} 
between CSR and MNE literature are very embryonic, as Husted and Allen (2006) indicate that the lack of scholarly attention is one of the reasons that MNEs often fail to respond effectively to issues of CSR in many host countries. To put it concretely, CSR has attracted a huge amount of attention by those who study Strategic Management (e.g., CSR by local firms in domestic markets), Marketing (e.g., the influence of CSR on customer loyalty), and Financial Economics (e.g., the relationship between CSR and stock market returns), but scholars in International Business (IB) have significantly overlooked the strategic importance of CSR. According to Campbell, Eden and Miller (2012), host-country stakeholders often lack information about a foreign affiliate, and may use stereotypes or impose idiosyncratic criteria compared with a host-country firm, with negative consequences, which forces MNEs to deal with significant liabilities of foreignness in host markets.

In this situation, CSR investments may be a practical non-market coping mechanism for reducing the liabilities encountered by MNEs in overseas countries, and thus MNEs should be strategically motivated to engage in host-country CSR. However, Waldman, de Luque, Washburn and House (2006) point out that the diffusion of awareness of the value of CSR practices in the global market has been occurring, but little is known about the factors influencing such practices. Hence, we will attempt to fill this research gap. Although there are in fact welcome exceptions (e.g., Maignan \& Ralson, 2002; Lynes \& Andrachuk, 2008), most of them have focused on the strategies of MNEs in the developed world (Yang \& Rivers, 2009). It is crucial that we understand how MNE subsidiaries approach CSR in emerging markets, so that we recognize the challenges the subsidiaries face in aligning their CSR approaches with local practices.

Korea is often referred to as one of the most dynamic emerging markets that have 
successfully achieved rapid economic development (i.e., Goldman Sachs has used the term "MIST", abbreviating Mexico, Indonesia, South Korea and Turkey, to categorize the country as one of the leading emerging markets and has stated it as an important market guaranteeing abnormal returns to MNEs in the long-run). In this vein, it is frequently considered as a good benchmarking target both for other emerging countries and MNEs which are eager to enhance economic and financial performance. This clearly suggests that an empirical examination of CSR practices in the Korean market will potentially provide valuable implications for MNEs to predict how local CSR activities would be enacted in a growing marketplace.

Another gap that needs to be addressed is associated with organizational size in that it is identified as both vital but relatively unexamined. Small and medium-sized enterprises (SMEs) constitute over $90 \%$ of the worldwide population of businesses and make significant contributions to employment, wealth creation, investment, innovation and international trade (Udayasankar, 2008). Within the limited, but growing, literature on SME ethics, however, scant attention has been paid to the issue of CSR (Worthington, Ram \& Jones, 2006). This pre-occupation with larger organizations is all the more amazing when one considers the social and economic importance of smaller firms (i.e., small and medium sized MNE subsidiaries (SMMSs)) to modern international business.

The reason why extant literature focuses on large subsidiaries is because subsidiary size may mean strategic importance for MNE headquarters, but due to the intrinsic differences between large subsidiaries and SMMSs, CSR is a different issue when applied to SMMSs. In addition to size as one criterion, the intrinsic differences include legal form, sector, orientation towards profit, historical development and institutional 
structures (Pirrini, 2006). Russo and Pirrini (2010) clearly indicate that a knowledge gap exists in the CSR-SMMS relationship and researchers are still far from constructing a consolidated and generally accepted model to investigate such relationships as well as providing a responsible perspective on the management of SMMSs. This reasoning suggests that we need to gain a better understanding of the antecedents affecting MNE CSR in emerging countries with research also putting emphasis in further exploring the behavior of SMMSs towards CSR.

\section{Literature Review and Theory Development}

\section{Theoretical Background}

Although there appears to be broad agreement that MNEs should behave responsibly, there is only limited discussion linking the MNEs and their CSR activities in emerging markets (Polonsky \& Jevons, 2009). Clear evidence verifying this situation can be found from Kolk and van Tulder's (2010) commentary arguing that while often mentioned as relevant topics for the study of MNEs, the number of articles trying to connect MNEs and CSR has been very limited, and the literature is in its infant stage. Various elements might contribute to the current phenomenon but the main cause of this situation is closely associated with the lack of available data. There are hardly any extensive databases providing information particularly on CSR or on the impact of MNEs on the various dimensions of sustainable development which can be used for IB research purposes. In addition, the problem of the lack of large-scale research material is more serious when the issue is applied to SMMSs in emerging markets. As primary data collection is very difficult and time consuming, this seems to be another reason behind the focus on large organizations and the main research foray into developed 
countries. Given the variation of CSR in the respective national business systems and potential IB opportunities in emerging economies, the latter concern (i.e., previous focus on developed countries) uncovered during the process of the literature review should not be ignored.

Developing a clearly defined corporate CSR identity for global organizations is complex, but it is generally defined as the voluntary integration of social concerns in business operations abroad and in their interaction with local stakeholders (Vilanova, Norazo, \& Arenas, 2008). Within the CSR perspective, Waldman et al. (2006), subsequently supported by Mishra and Suar (2010), suggest that stakeholder theory helps to understand the dimensionality of CSR values, provides a useful direction in the evaluation of CSR, as well as to offer a new way to organize thinking about organizational responsibilities. Whether driven from corporate ideology or from stakeholder obligations, MNEs encounter a complex set of decisions in regards to how they respond to CSR issues (Polonsky \& Jevons, 2009). Thus, firms should consider all stakeholders, which are "groups and individuals who can affect, or are affected by, the achievement of an organization's mission" (Freeman, 1984, p. 54). According to stakeholder theory, the relationship between the corporation and the stakeholder is mutually interactive, and thus the firm ought to be managed to meet the expectations, including CSR issues, of all its stakeholders. Under this idea, we will seek to systematically address MNE CSR by using stakeholder theory as an overarching theoretical lens.

The basic instinct of corporations is to maximize shareholders benefits by undertaking actions that increase business profit. However, a variety of stakeholders surrounding firms also prefer to interact with organizations that evince better CSR 
(O’Shaughnessy, Gedajlovic, \& Reinmoeller, 2007), which suggests that even when a firm tries to serve its shareholders as a primary concern, its success in doing so tends to be affected by other stakeholders. In this regard, in order to avoid conflicts with stakeholders and effectively carry out relationship-specific investments with them in resources and processes, firms increasingly need to take corporate stakeholders into account (Gifford, Kestler, \& Anand, 2010; Udayasankar, 2008). According to Luo (2006), from the MNE standpoint, such an idea started taking shape with the realization that firms have social responsibilities and social responsiveness towards the local economies in which they operate. His explanation infers that MNEs have ethical obligations to conduct worldwide business in a way that safeguards the welfare of society and are expected to be society-oriented (also see Carroll, 1991).

There are a large variety of entities that maintain a "critical eye" on CSR. Broadly speaking, stakeholders forming the connections between the aims and ambitions of the MNEs and the expectations of society consist of primary and secondary stakeholders. Stakeholder theory sheds light on the role of the primary stakeholders by pointing out that organizational survival and success hinges on the organization's ability to generate sufficient wealth, value, or satisfaction for its primary stakeholders, though not exclusively for shareholders (Maon, Lindgreen, \& Swaen, 2009). Those whose relationships are crucial for the organization to realize its mission in producing goods or services include 1) consumers, 2) internal managers and employees, 3) government, 4) suppliers and 5) investors. Secondary stakeholders are comprised of social and political actors functioning as supporters of the mission by providing their tacit approval of the MNE's activities, thereby making them acceptable and giving the business credibility. Such secondary stakeholders may include 1) competitors, 2) media, 3) local community, 
and 4) non-governmental organizations (NGOs) (Maon et al., 2009).

\section{Importance of CSR for SMMSs in Emerging Economies}

Although MNEs discover new business opportunities in emerging markets, it is difficult for them to obtain legitimacy for their local operations (Reimann, Ehrgott, Kaufmann, \& Carter, 2012). The host economies generally lack information about MNE subsidiaries (particularly SMMSs), and thus commonly use stereotypes or different standards to judge business activities of foreign firms with skepticism (Gifford et al. 2010). In addition, compared with large organizations, SMMSs do not possess sufficient competencies and have a difficulty in accessing necessary resources, which make them more vulnerable to local business environments. As a result, SMMSs need to build legitimacy to successfully operate in these regions.

The challenges of legitimacy occur from institutional distance associated with unfamiliarity and discriminatory treatment (i.e., liability of foreignness) (Campbell et al., 2012). If SMMSs do not adapt to unacquainted environments in host countries, they may suffer unpredictable costs. In particular, compared to developed markets, emerging economies are relatively uncharted territories for most MNEs, and thus they may need to try to overcome the institutional distance and reduce these costs by engaging in local CSR activities (Yang \& Rivers, 2009; Gifford et al. 2010).

Institutional theory supposes that firms are surrounded by formal and informal institutions (North, 1990). The formal institutions have coercive influences, such as national legislation and government regulation, whereas the informal institutions include cognitive issues, such as norms, conventions and shared beliefs. Firms come under various social and cultural pressures to comply with their institutional 
environments for legitimacy and social fitness (Scott, 1995). Responding to these pressures, the SMMSs, which suffer a lack of resources relative to large subsidiaries, are enforced to adapt their processes, decision-making and business activities to become adequately embedded in local society. In this vein, it is expected that SMMSs' CSR structures and practices adopted through the process of institutionalization play a pivotal role in enhancing recognition and trust in host economies and creating good partnerships with local stakeholders.

In other words, local legitimacy is acquired by conforming to rules and value systems made up by society members, and thus the institutional pressures are closely related with local stakeholders' demands (Yang \& Rivers, 2009; Reimann et al, 2012). For example, SMMSs may comply with norms and certifications required by business networks and understand and adapt the values of both primary and secondary local stakeholders. Under this premise, this paper develops a comprehensive stakeholderbased framework to identify local institutional pressures imposing CSR on SMMSs in an emerging market.

\section{Primary Stakeholders}

Consumers: Among all the stakeholders, one important group that appears to be particularly influential for firms to initiate CSR activities is consumers. According to evidence found by Du and Sen, (2010), consumers tend to switch from one brand to another (price and quality being equal) if the other brand is associated with proactive corporate citizenship. In addition, $85 \%$ will consider boycotting a firm's products or services by switching to another firm's offerings in the case where consumers think that the initial firm shows negative corporate responsibility practices. Mishra and Suar 
(2010) suggest that if consumers know that a certain good is produced by a socially responsible firm, they have a propensity to provide positive inferences about the product. Such inferences induce consumer loyalty and turn consumers into company/brand ambassadors and champions who engage in advocacy behaviors.

Lamberti and Lettieri (2009) also argue that as consumers become aware of the ethical implications of a firm's behavior, they develop a trust in the belief that the firm will maintain its quality standards in order to enhance corporate reputation. In the same vein, beyond ethical considerations, consumers' perceptions of CSR deficiencies can be extremely detrimental to corporate profitability and growth. A noteworthy point here is that such a detrimental effect derived from irresponsible behavior by firms makes MNEs more vulnerable in foreign markets as MNEs already commonly suffer from the liability of foreignness (Gifford et al., 2010; Kolk \& van Tulder, 2010; Zahee, 1995). SMEs, including MNE subsidiaries, are different from larger firms in their structural, social, functional attributes, and other characteristics, such as a lack of high-quality internal resources, financial constraints, and relatively small market share. Given these issues, we can conclude that consumer patronage stemming from CSR practices and business ethics is considerably critical for foreign investing firms and even more for SMMSs.

Hypothesis 1: Consumers play an important role in influencing CSR practices of SMMSs in foreign markets.

Internal Managers and Employees: One relevant stakeholder that directly influences corporate CSR is the managers and employees of an organization. Corporate policies 
and practices towards union relations, remuneration policy, working conditions, and elimination of forced/child labor are commonly determined by managers (Mishra \& Suar, 2010). This means that managers are firm-specific factors functioning as a key basis in orienting the organization and its decisions and behaviors particularly associated with CSR. In addition, managerial support not only for environmental and social initiatives but also for the presence of policy entrepreneurs positively affects an organization's citizenship orientation (Lindgreen, Swan, \& Johnson, 2009a). In this vein, there cannot be socially responsible MNE subsidiaries without socially responsible managers who have the willingness to sacrifice corporate objectives, strategies and resource allocation in favor of socially responsible actions in foreign markets (GodosDíez, Fernández-Gago, \& Marínez-Campillo, 2011).

Moreover, the role played by top management is perhaps more important for SMMSs to keep good and stable stakeholder relations and communicate clear and strong ethical business values with their relatively small foreign investment. According to Hanke and Stark (2009), corporate values are mainly chosen and implemented personally by the managers in SMEs. That is because, unlike large firms, SMEs do not generally possess sufficient organizational resources to be simultaneously and fully allocated, and a manager's personal perceptions for public tasks are logically more crucial in small firms than firms with many employees.

Similarly to managers, O'Shaughnessy et al. (2007) explain that a lot of work in CSR adopts the assumption that CSR is driven by firm specific factors, such as internal employees. In other words, employees may also considerably influence the process from planning to implementation of a subsidiaries' CSR activities. Human resource practices, compensation policy, working environments, and elimination of forced/child 
labor, portray a firm's CSR towards employees (Mishra \& Suar, 2010). By upgrading such corporate standards, firms are able to satisfy employees, increase their job commitment, and improve financial and non-financial performance, and ultimately secure internal momentum for CSR. We thus believe that CSR is an issue that suggests a reference to the personal interests of the managers and employees of SMMSs. Hence,

Hypothesis 2: Internal managers and employees play an important role in influencing CSR practices of SMMSs in foreign markets.

Governments: Government policies are one of the primary keys in encouraging a greater sense of CSR by exercising strong influence in shaping the context of economic actions as part of the rules of the game. Under this premise, we suggest that governments that enact CSR regulations are effective in establishing social expectations about responsible corporate behavior and in promoting the idea that firms play an important role in addressing social problems. Hung (2011) also argues that firms are affected by the political environment in which they operate. According to him, in order to secure sustainable competitive advantages, a firm needs to use its organizational resources to undertake socially responsible actions for effective interaction within the political and legal environment. Through planned activities, which satisfy government demands, firms strive to influence the politically relevant elements of its external environment. Many governments seem to have an increasing interest in CSR performance by MNEs and attempt to supervise the behavior of foreign firms, in effect forcing them to be "good corporate citizens" in local markets (Husted \& Allen, 2006). Previous studies also shed light on the role of local governments in improving MNE CSR. For example, Manakkalathil and Rudolf (1995) document that MNEs operating in 
underdeveloped countries generally find that regulatory environments are less sophisticated than those in their home countries, and thus they have a propensity to show unethical behavior in these countries. Luo's (2006) experiments show that the interaction between MNEs and local governments is a complex, dynamic, and interdependent process in which MNEs escalate their relationships with governments to demonstrate their CSR activities and receive favorable treatment. Other studies indicate that CSR efforts aid MNEs in building local legitimacy and strong local relationships with host governments, and it is possible to consider political conditions as a potential factor in interpreting an MNE's decision to engage in CSR (Hadjikhani, Lee, \& Ghauri, 2008). The same logic can be applied to SMMSs.

Hypothesis 3: Local governments play an important role in influencing CSR practices of SMMSs in foreign markets.

Suppliers: According to the stakeholder perspective, the supplier relationship is part of the dynamic evolution of positive-sum strategies that create benefits for firm performance over time. Avetisyan and Ferrary (2013) argue that suppliers are an important stakeholder, which are directly involved in economic processes, while being simultaneously bound by explicit contracts with a company. Freeman (2004) also proposes that to be recognized as socially responsible, an organization should take into consideration the interests of suppliers, as it has a strong impact on organizational performance outcomes. In addition, local suppliers in many host countries have shaped the concept of CSR through their expectation that MNE subsidiaries will act responsibly in the conduct of their operations (Bondy, Moon, \& Matten, 2012). In this vein, 
suppliers may represent the true challenge ahead, and the management of these relationships is the starting point from which to frame an approach to fruitful internationalization in a more integrated ethical view (Ghauri et al., 2008).

According to Cheng and Ahmad (2010), those who address the issue of suppliers commonly agree that MNE subsidiaries need to carefully observe the demand of their supply chain. This comes about due to the growing insistence that responsible firms look at the impact not only of their own operations, but that of their business partners. They further emphasize that having good supplier relations are essential for MNE subsidiaries in that CSR practices for their supplier and business partners are connected to legal concerns and subsidiaries are not able to establish or maintain a business relationship with a supplier in cases where their practices violate local laws relating to labor standards or environmental protection. Building competitive advantages from a CSR approach in foreign markets logically requires MNEs to respond to their local business and institutional environments (i.e., local responsiveness). In this situation, local suppliers are an influential stakeholder to be considered in the new business environment to show commitment and local responsiveness (Cruz \& Boehe, 2010). In particular, large subsidiaries are expected to hold more bargaining power in negotiations with their suppliers, but SMMSs face the challenge of enforcing CSR standards throughout the supply chain (Torugsa, O’Donohue, \& Hecker, 2012). In this regard,

Hypothesis 4: Suppliers play an important role in influencing CSR practices of SMMSs in foreign markets. 
Investors: Scalet and Kelly (2010) raise a basic question about why the CSR movement is progressing and answer that CSR is always, and only, a question of how to differentiate one's product to satisfy investor demand. Such anticipation is probably plausible in that investors have a propensity to show willingness to pay a premium for the stocks of firms which are socially responsible (Mishra \& Suar, 2010). Suppliers of capital may prefer to do business with firms exhibiting strong social performance because their cash flows may be perceived to be at less risk and less prone to negative performance (O’Shaughnessy et al., 2007).

In addition, institutional investment selection based on CSR is quite common in most developed economies (i.e., the main investors). For instance, institutional investors in the U.K. are subject to a set of regulatory, institutional and social pressures to encompass social performance in investment selection. These investors hold power in shaping firms' CSR behavior and holding MNEs responsible for high international CSR standards. In the U.S., socially responsible investment (SRI) is no longer an option for investors, but an imperative, as argued by Adam and Shavit (2008), SRI decreases the long-term level of risk on the investment and concerns the long-term survival and growth of the firm. Influence by investors thus represents a formidable force that can effectively stop commercial cooperation and business relationships if MNE subsidiaries appear socially irresponsible in foreign markets. Investors can perhaps be a particularly large and powerful stakeholder in the case where subsidiary size is a small or mediumscale company, which logically suffers from a lack of organizational resources, along with the liabilities of foreignness. This leads to the following hypothesis:

Hypothesis 5: Investors play an important role in influencing CSR practices of SMMSs 
in foreign markets.

\section{Secondary Stakeholders}

Competitors: The concept, 'following leading companies' used in Laudal (2011) refers to a process whereby firms try to imitate and excel in CSR practices of competitors to seek a competitive advantage or to increase their legitimacy. That is, MNEs may try to enhance their compatibility with environmental characteristics and overcome uncertainties and ambiguities in their surroundings by imitating the practices of their competitors in foreign markets. Similarly, Bondy et al. (2012) suggest that MNEs tend to identify their existing CSR meanings and activities and looked into competitor activity to maintain a market position through monitoring the competitor's CSR strategies. Cruz and Boehe (2010) also indicate that CSR may help an MNE to successfully differentiate itself from its competitors and thus become a means to achieving competitive advantages.

Bondy et al. (2012: pp.292-294) argue "most MNEs were quite open about tracking the activity of their perceived 'CSR competitors'. These corporations observed the justifications and activities of their CSR competitors, to both map the CSR marketplace and identify activities to emulate. For most of the MNEs, this was to keep pace with competitors. Every MNE in the research engaged in some degree of tracking their CSR competitors. Some did so through participation in collaborative or bestpractice-sharing groups such as the Ethical Trade Initiative, UN Global Compact or industry bodies. However, most focused on their competitors' CSR reports and policies to identify changes in CSR activity so as to improve their own practice... They could then brand or market these initiatives as something different to their competitors but 
signal an overall emphasis on acting responsibly". O'Riordan and Fairbrass (2008) presume that MNEs particularly need to do so, because competitors may also engage in activities that perhaps emphasize or publicize the alleged faults of their competitors.

These reasons all potentially directly link with motivations that MNE subsidiaries undertake CSR programs in foreign environments. Meanwhile, recent research suggests that SMMSs generally possess several distinctive organizational characteristics, such as better entrepreneurial alertness and simpler capital structures that can considerably endorse organizational efficiency and flexibility, and innovativeness with which to promptly respond to their competitors' actions (Torugsa et al., 2012). These attributes are held to contribute substantially to competitive advantage built on CSR principles and sought after for SMMSs to be aligned with their competitors. Thus,

Hypothesis 6: Competitors play an important role in influencing CSR practices of SMMSs in foreign markets.

Media: O'Riordan and Fairbrass (2008) argue that there is a growing sense of public disapproval in activities by MNEs. One likely reason causing this negativity associated with MNEs is the repeated occurrence of certain high-profile events, labeled by many as 'scandals'. This behavior has frequently been emphasized through intense attention from the media, which have grabbed the opportunities to publicize alleged failings. Han, Lee and Khang (2008) find a typical example, malpractice in CSR causing serious damage to Nike's corporate image, and they shed light on the case as solid evidence showing how reputation and organizational performance are closely connected. 
According to their explanations, Nike's share value plummeted reflecting the revelation that Nike used sweatshop labor in Vietnam in 1996. The situation did not improve until Nike enacted vigorous CSR programs in order to change its corporate image.

This clearly points out that media significantly contributes to fulfilling the 'right to be informed' by reporting, for instance, the public policy-making process, exposing corrupt acts, creating public opinion and general awareness (Azmat \& Samaratunge, 2009). Media has thus recently emerged as a crucial stakeholder to accelerate MNE CSR in global marketplace, and works to promote good governance and responsible business practices and is voicing the concerns of the community (Azmat \& Samaratunge, 2009). In particular, when we consider SMMSs suffering investment risks in unknown foreign markets, but do not own sufficient organizational tangible or intangible assets we can easily forecast how corporate brands, identities and reputations influenced by media exposure are important for them to overcome this challenge. In this vein, the critical role of the media as a stakeholder should be acknowledged.

Hypothesis 7: Media plays an important role in influencing CSR practices of SMMSs in foreign markets.

Local Community: Essential attitudes on moral rights and obligations reflect a set of standards to which all societies can be held, and 'local' CSR deals with the firm's obligations based on the standards of the local community (Husted \& Allen, 2006). Thus, MNEs need to appropriately evaluate and respond to claims by the local community relevant to their "license to operate" in local markets (Russo \& Perrini, 
2010). Social activists have also been forcing MNEs to focus on CSR efforts and this voice is increasingly being echoed by local communities in which the firms operate. As is often the case, the activities of the MNEs are under more intense scrutiny from local communities (Torres-Baumgarten \& Yucetepe, 2008). While MNEs attempt to meet the demands of local communities, they benefit from being recognized as an embedded part of the community in which they are doing business.

Typical business involvement within the community, which generates such benefits, is seen in many areas, such as education, health, and income generation. CSR activities towards a community are seen in terms of philanthropic giving, public-private partnerships, community relationships, and participation in social and economic development issues (Mishra \& Suar, 2010). In addition, when MNE subsidiaries focus their social actions within communities in local markets, they reap the benefits of a socially responsible image among their local employees and the local community (Lindgreen et al., 2009a). In particular it has been observed that investments in the enhancement of relationships with the local community aid MNE subsidiaries in obtaining competitive advantages through tax savings, decreased regulatory burdens, and improvements in the quality of local labor (Waddock \& Graves, 1997). Moreover, an important issue that should be noticed is that social activism used by local community groups as a stakeholder should be much more influential for SMMSs than large foreign organizations possessing organizational power. Hence,

Hypothesis 8: Local communities play an important role in influencing CSR practices of SMMSs in foreign markets. 
NGOs: Doh and Guay (2006) point out that the rising influence of NGOs is one of the most significant developments in international business over the past 20 years, and NGO activism has been responsible for major changes in CSR behavior. That is, NGOs recently have moved to the front in discussions on MNE CSR, using their status as stakeholders to push for change in local markets (Guay, Doh, \& Sinclair, 2004). More specifically, stakeholders are able to show a link between the local social issues and the business activities of the focal MNE subsidiary. By expressing a particular ethical claim, stakeholders draw attention to this causal relation. For example, an environmental NGO can potentially establish a causal connection between air pollution and the emissions of a particular MNE subsidiary. Hence, the NGO may pressure the MNE to reduce the factory's emissions (Pater \& van Lierop, 2006).

This clearly indicates that NGOs influence MNE policy and subsidiary operations, and this influence can take several forms: public announcements, shareholder proposals, direct negotiations with managers, and proxy contests (Guay et al., 2004). Similar discussions can easily be found from related literature. For example, Arenas, Lozano and Albareda (2009) suggest that MNEs often change their policies and strategies in cases where social and political pressures are linked to particular NGOs or NGO networks. Van Huijstee and Glasbergen (2010) mention a parallel opinion by explaining that the number of interactions between MNEs and NGOs concerning issues of MNE CSR has exponentially increased in the current business climate. Under the influence of NGO pressure and the reputation risks this entails, business increasingly accepts the social responsibility in solving local issues, and engages NGOs in their CSR efforts. The same researchers also confirm this statement through an empirical examination and argue that business-NGO interactions lead to CSR changes and they 
include advances in CSR policies (formalized documents), practices (informal routines), and structures (staff positions and departments) within MNE subsidiaries under the influence of the NGO. We should note that SMMSs must not be an exception from the logic discussed above. In this regard,

Hypothesis 9: NGOs play an important role in influencing CSR practices of SMMSs in foreign markets.

\section{Methodology}

\section{Sample and Data Collection}

The population of this research is MNE subsidiaries, which are located in the South Korean market (South Korea will be referred as Korea, hereafter). The list of all subsidiaries was attained from Foreign Direct Investment published by the Ministry of Knowledge Economy (2011). This source covers all foreign investment activities undertaken in the country and the information on inward FDI in Korea is reliable and trustworthy in that most of the recent empirical examinations exploring 'FDI in Korea' have used the same data (e.g., Park, 2011; Park \& Ghauri, 2011). Although this is official government information, we have also visited the corporate homepages of the companies to ensure against the possibility that some MNEs might have withdrawn their foreign investments or terminated contracts with local firms resulting in the closing of the subsidiary operation. Thus, we did not include firms whose corporate homepages we were unable to find and through this process, a total number of 1,531 firms were finally compiled.

A questionnaire through postal survey was used to collect data for statistical 
analysis. The survey was distributed between September and December 2013, and CEOs were regarded as the best informants (Hence, questionnaires were sent to them. The follow-up letter was sent to those who had not responded in the fourth week. For the follow-up letter, a postcard was used to say early thanks to respondents and to remind about the return of the questionnaire). When the survey was done, a total of 335 responses were returned, giving a response rate of $21.88 \%$. However, 13 responses were not usable (some respondents merely repeated a certain numeral or recurrently enumerated figures in consecutive order), and thus they were discarded. Renuka and Ventakeshwara (2006) propose that the definition of SME by size is different across the globe and the way it is defined hinges on the stage of economic development of the country concerned. According to the Scope of Korean SMEs (2010) published by the Korean Small and Medium Business Administration, SMEs are firms with fewer than 300 employees. Based on that criterion, 11 subsidiaries were additionally excluded, which means 311 responses were finally selected for examination. Prior to analysis, we checked the presence of non-response bias by using key parameters (detailed industry classification and origin of MNEs as well as early versus late respondents). We found no significant difference between the responding and the non-responding subsidiaries regarding two key parameters and significant differences between the early respondents and the late respondents were not found.

However, utilization of a single process generally involves some weaknesses in drawing robust results. To overcome this risk, we obtained further insights into the topic by conducting focus groups with primary and secondary stakeholders. The focus group is one of the techniques producing qualitative data that provides insights into the attitudes, perceptions, and opinions of participants through carefully designed 
discussion, and it is useful for the following two reasons (Krueger, 1994; Ghauri \& Gronhaug, 2010). First, the real value of the focus group is in supplementing the information obtained through the questionnaire survey. The questionnaire and the focus group have complementary characteristics. The questionnaire typically generates a considerable amount of data, whereas the focus group can offer preliminary insights about the attributes of the information. Second, another value is detected in the opportunity to examine the interactions between participants.

The focus group is particularly helpful when it comes to analyzing what participants believe. This is because they are not only eloquent about their own views and experiences, but also illustrate to the other group members why they grasp their opinions or challenge those which might differ from their own views (Sekaran, 2003). Through the interactions among participants in such a natural environment, the focus groups is aimed to uncover reasons from statistical analyses. The Korean Ministry of Trade, Industry and Energy helped in the recruitment stage by introducing the participants, and thus its aid was very useful in conducting the focus groups. In addition, two focus groups (i.e., seven and eight stakeholders respectively in each group) were chosen to avert the serious possible danger that a single group of people would provide prejudiced, unfair opinions, and the interviews were undertaken on $6^{\text {th }}$ and $12^{\text {th }}$ January 2014 (participants are two consumers, two managerial employees, two government officers, four CEOs (i.e., two supplier firms and two competitors), an investor, a media representative, a local community member, and two NGOs).

\section{Variable Measurement}

The level of CSR activities by MNE subsidiaries is a dependent variable, and it 
was assessed by a twelve-item scale based on 5 point Likert-type scales. Both primary and secondary stakeholders comprising nine factors are independent variables potentially influencing the phenomenon. As might be noted from the explanations on variable measurement, we asked respondents to assess perceptually both dependent and independent variables, indicating that there is a possible presence of common method bias. To remedy this limitation, we have taken the following precautions: First, several individual items (i.e., multi-item scales) were used to measure the independent variables based on earlier literature. In addition, validated items by previous studies were employed by extensively reviewing the extant literature on similar topics (e.g., CSR, corporate social performance, corporate citizenship and ethics). Second, once the survey was completed, we interviewed 10 respondents for the purpose of confirming response consistency, but we did not find a considerable difference between the respondents' interview reports and their survey answers (Luo, 2006).

Third, we also re-sent the same questionnaire to different people (e.g., general managers) of 50 sample firms, whose executives (CEOs) had responded to our survey earlier. We received 21 responses and we did not uncover any significant inconsistencies between the two respondents from each firm (Park \& Choi, 2014). Fourth, following Podsakoff et al. (2003: 889), who suggest "One of the most widely used techniques that has been used by researchers to address the issue of common method bias is what has come to be called Harman's one-factor (or single-factor) test," we entered all variables measured subjectively by the respondents into this testing method. The proportion of variance criterion exhibits four independent dimensions. The variables 'consumer', 'internal managers and employees', 'investors', 'local community' and 'CSR' have high loadings on the first factor (27.79\%); and 
'institutional distance', 'government' and 'competitors' have high loadings on the second factor (13.40\%); and 'media' and 'NGOs' have high loadings on the third factor (12.86\%); and 'suppliers' has high loading on the fourth factor $(11.62 \%)$.

According to Podsakoff et al. (2003), the presence of a substantial amount of common method should be suspected in the case where (1) a single factor emerges from the factor analysis or (2) one general factor accounts for the majority of the covariance among the measures. The comments given by Podsakoff et al. (2003) and the outcomes from the analysis clearly confirm that this research does not suffer common method bias. A detailed description on the variable measurement is provided in Appendix A. It also shows information on sources of each variable measurement and Cronbach's alpha.

In addition, the average variance extracted (AVE) was calculated for rigorous testing of measurement validity. Fornell and Larcker (1981) assert that the AVE should be greater than the recommended 0.50 to achieve convergent validity. As shown in Table 1, we document that the AVE values are greater than 0.50 for all constructs $(0.507<$ all AVE values $<0.653)$, which provides strong evidence of convergent validity.

Discriminant validity was evaluated by comparing the AVE estimates for each construct with the square of the parameter estimates between two constructs. According to Fornell and Larcker (1981), discriminant validity is achieved if the AVE of each construct exceeds the square of the standardized correlations between the two constructs. All AVE estimates are greater than the squared correlations between all constructs. Thus, both convergent validity and discriminant validity are established (see Table 1).

Five variables were additionally included to control the effects of other factors on the MNE CSR: (1) development status of MNE origin. MNEs from developed economies, such as USA, Europe or Japan, are perhaps more familiar with CSR than 
other firms mainly based in developing countries. Thus, a dummy variable was created ( 1 for subsidiaries established by MNEs whose corporate origins are developed countries and 0 otherwise). (2) Ownership structure. The proportion of equity that MNEs possess might also affect MNE motivation to contribute to local societies and markets (it was measured by the proportion of foreign ownership). (3) Institutional distance. It was measured by average of three questions on the level of dissimilarity in regulatory, cognitive and normative institutions between home and host countries. In addition, MNE CSR can also be influenced by (4) organizational size and (5) age. Size was calculated by the number of employees, whereas age was measured by the number of years since creation of the subsidiary, respectively.

\section{Result and Discussions}

We attempt to identify cause-and-effect relationships, and consider stakeholders influence causing MNE CSR practices in local economies. The most common analysis strategy for such a research design is using an OLS regression technique (Hair, Anderson, \& Tatham 1987). Prior to undertaking the analysis, we assessed the level of multicollinearity by observing correlations between variables (See Table 1). Although researchers suggest different cut-off points at which multicollinearity is defined and we conservatively take into account the possibility (For instance, Tabachnick \& Fidell (1996) advise .70, Kim (2005) proposes .80, and Pallant (2001) recommends .90, respectively), the problem of multicollinearity is negligible. In addition, we also ran the variance inflation factor (VIF) to more minutely verify the non-existence of multicollinearity. Although Hair, Babin, Money and Samouel (2003) argue that 5.0 is a maximum acceptable VIF value, the highest value of VIF is less than 3.6 in our model, 
which confirms that multicollinearity is not problematic in carrying out OLS regressions.

*** Insert Tables 1 and 2 about here ***

Table 2 exhibits the results of the OLS regression analyses. Control variables and predictors associated with primary stakeholders are employed in Model 1, whereas control and independent variables related to secondary stakeholders are included in Model $2^{2}$. In contrast, Model 3 is a full model. The results indicate that all regression models are highly significant $(\mathrm{p}<0.001)$.

This research started with the anticipation that primary stakeholders function as a vehicle to expedite CSR practices by MNE subsidiaries in local markets. For many subsidiaries, CSR is seen as an important means of influencing the feelings, thoughts, and consequently purchase patterns of their target consumers. Thus, consumers are one of the most critical catalysts promoting CSR activities of an organization (Mishra \& Suar 2010). 'Managers and employees' are also significant change agents and their awareness of and commitment to CSR are widely considered as another key element for the implementation of social and environmental initiatives (Godos-Díez et al., 2011). As expected, the results from the regression models also suggest that both 'consumers' and 'managers and employees' have a significant effect on CSR behaviors and thus H1 and $\mathrm{H} 2$ are supported. This clearly indicates that both factors do not only enhance the

\footnotetext{
${ }^{2}$ Control variables are generally insignificant, which denotes their minimum influence on subsidiary CSR. However, as institutional theory suggests, our results reveal that institutional distance negatively motivates MNE subsidiaries to conduct CSR activities in foreign markets. Although we do not discuss its impact here as it is not our research focus, we recommend that future research examines the relationship between institutional distance and MNE ethics, such as CSR and corruption as potential paths for further studies.
} 
organizational will in ethical activities but also highly expedite the fulfillment of corporate citizenship behavior. In line with this study, a number of extant empirics confirm their considerable impact on CSR (e.g., Hanke \& Stark, 2009; Lamberti \& Lettieri, 2009). A manager participating in a focus group interview also confirmed the influence of consumers on CSR by saying that:

"Of course, consumers are an important stakeholder influencing a firm's decision-making because it can raise brand awareness and improve sales and growth only when it successfully meets consumers' CSR expectations".

A consumer also expressed her identical opinion with the manager (for the reader's information, Yuhan-Kimberly is an international joint venture established between Korean and American firms. It mainly produces paper handkerchiefs and is famous as a firm vigorously engaged in an environmental protection campaign in Korea).

“For example, we know Yuhan-Kimberly's public service practices carried out in our society. Therefore, when we see both the products by Yuhan-Kimberly actively conducting CSR and similar other products at supermarkets, consumers generally buy the products produced by the former firm. Another example is a recent dumpling shock. Consumers never buy dumplings that include harmful ingredients to our health. I believe firms cannot disregard consumers' expectations as consumer trust is difficult to be built up".

A CEO states managers and employees as the second consumers and highlights,

"Managers and employees are the second consumers. If the image of their firm where they are working is good, then their self-esteem and loyalty to their firms should be enhanced. This fact functions as a catalyst motivating international firms to conduct extra CSR activities, which confirms that internal managers and employees are major stakeholders for CSR. Moreover, if the employees' expectations for CSR are high we cannot just ignore them. Company operations cannot be run by one-way management but must be efficiently handled by communication between management and employees at the moment. Thus, the role of managers and employees is becoming more important". 
Unexpectedly, H3 was rejected, as government is insignificant in all models. According to our focus group interview, governments in emerging markets seem to have little understanding of the necessity to improve MNE performance of CSR in local economies. Although a government officer argues,

"Similarly to other stakeholders, the government also plays some central roles for CSR. Governments have organizations, like 'Fair Trade Commission' and 'the Financial Supervisory Service' and that is clear evidence. Also, governments try to provide incentives to MNE subsidiaries doing philanthropic work by giving tax cuts in the local market".

A CEO points out, "I agree that there exists governmental regulations on environmental pollution. But the government does nothing on general CSR, except for that". Another CEO positively responds to this opinion and says:

"The government is not a main agent emphasizing CSR in Korea yet. I think, the American government forces firms to return at least $10 \%$ of total profits to society, and as far as I know, even the Chinese government tends to push firms to be good citizens. But we do not have such a system. Therefore, Korean firms and international subsidiaries spontaneously conduct their CSR without government's official requests. Korea is not an advanced country and Korean government generally lacks cognition on the importance of CSR".

When we blend descriptions above with statements given by an additional CEO running an MNE subsidiary in the Korean market, the reason for the insignificant association between government and subsidiary CSR is perhaps understandable. He points out,

"MNEs normally investigate local markets that they want to enter in advance prior to their investments. If they think CSR regulations are not well formulated in the local market they do not feel a necessity to undertake CSR". 
Interestingly, suppliers influence is statistically significant, but the significance is negative. This is contrary to the argument of Lindgreen et al. (2009a) as they suggest that a key driver of MNE subsidiaries to be responsible is accountability to their suppliers in the local supply chain. That is, local suppliers may request MNEs to demonstrate that their business operations satisfy environmental and ethical standards in local markets. Thus, the pressure for better ethical performance moves upstream through the value chain. Moreover, in the case where the stakeholder is a large and dominant organization, its pressure can be a formidable force particularly to SMMSs.

However, the results from the regression shown in Table 2 indicate that the citizenship behavior of SMMSs does not depend on the influence of local suppliers. This somewhat surprising result can be understandable if we refer to explanations provided by Lee and Yoshihara (1997), who examined the level of business ethics of Korean firms. According to them, since the dramatic economic development in Korea, Korean firms have tried to meet elevated social expectations on ethical issues, but their behavior is generally still far from socially responsible. These researchers expand their opinions and state that Korean firms perceive ontological corporate behavior as a necessary change for transparent business, but they do not fulfill the expectations by practicing it in an appropriate manner in the real world. As an example, top management operating a business in the market has a propensity to charge private expenses to the company account.

In addition, bribery is quite a common experience in business contracts when decisive decision-making is required. A more problematic point is that businessmen consider it a normal practice and others also do the same. The survey results from Choi 
and Nakano (2008) reveal similar reasoning. According to their survey, although Korean firms have achieved notable progress in implementing systematic measures to establish corporate ethics, undesirable customs (e.g., giving of unreasonable gifts, unfair gratuities and bribes) still exist in their business habits. We assume that while Koreans accomplished remarkably faster economic growth than other parts of the world (Bennett, 1999), this final outcome is largely emphasized more than business processes. This may imply that in order to obtain rapid economic developments in many emerging markets, local suppliers in these countries are less likely to focus on CSR. Due to the market characteristics, the negative influence of suppliers in emerging markets on CSR practices by SMMSs is perhaps a reasonable outcome. In addition, our focus group reveals an attention-grabbing fact, and a CEO insists the following (for reference, "Gap" means "a forceful firm", whereas "Ul” denotes "a powerless organization" in Korean jargon).

"No one may deny that in Korea, a buyer is a "Gap", and a supplier is an "Ul". In the Gap-Ul relationship, the influence of "Ul" is negligible. The relationship in Korea is not based on a win-win approach, but a supplier is a sort of subordinate. Thus, suppliers are not able to impact subsidiaries' CSR".

Likewise, we have not found a close association between investors and subsidiary CSR, which rejects $\mathrm{H} 5^{3}$. Participants in the focus group confirm the statistical results to characteristics of local investors and social atmosphere in Korea:

\footnotetext{
${ }^{3}$ We should probably acknowledge that in our research framework, we did not distinguish local investors from foreign shareholders, though they do not have identical characteristics. We suggest that future research needs to examine how they function differently and minutely investigate their roles for CSR, respectively.
} 
"As everyone knows, philanthropic culture in advanced countries is invigorated. On the contrary to those countries, we do not have the same culture. To be honest, I would like to leave my wealth only to my children. I am not interested in philanthropy or society's restoration".

These discussions may explain why investors do not play a pivotal role in enhancing subsidiary CSR in the local market.

Secondary stakeholders comprising competitors, media, local community and NGOs are other factors that are anticipated to be positively associated with MNE CSR. When MNEs attempt to penetrate into foreign emerging markets, they perhaps experience more liabilities of foreignness than entry into developed economies in that investments into emerging markets may encompass various risks stemming from many unknown business environments. Meanwhile, we need to note that secondary stakeholders, who are not directly engaged in business transactions, but still influence or affect, or are influenced or affected by the MNEs, are the ones primarily generating the business risks. In this vein, the maintenance of good relationships with secondary stakeholders is a prerequisite for MNEs to be successful in emerging markets, and in addition, CSR practices asked by the former can be a daunting stimulus particularly in the perspective of SMMSs which do not possess strong market power. These discussions indicate that the positive and significant association between secondary stakeholders and CSR practices in Model 2 is logically plausible.

As expected, competitors are confirmed as a strong push factor enforcing subsidiaries to ethically behave in the host economy. All participants in the focus group recognize the importance of the element without a dissenting voice. For example, a CEO contends,

If a competitor conducts CSR then I also have to do similar actions. If a competitor actively implements social contributions to Korean society, I have to imitate the behavior just in order to survive in the market. 
However, interestingly, local community loses its statistical power in Model 3, giving only partial support for H8. In order to explore the possible reasons for the results, we ran an additional regression (see Model 4). According to the result yielded by Model 4, the role played by local community is lessened in overseeing MNEs' ethical behaviors under the presence of local consumers owning a strong willingness to supervise MNE subsidiaries in emerging markets. The creation of a decent subsidiary image is an important key element that determines its performance abroad, and it is perhaps even more crucial for SMMSs to secure operations in relatively unknown emerging markets. In this situation, we presume that local consumers considerably affecting corporate reputation play a pivotal overseer role in forcing MNE subsidiaries to design strict ethical standards and embark on CSR activities in host countries. A bad reputation triggered by local consumers can be a lethal detonator inducing investment failure, and thus it could be deadly for SMMSs suffering from the liabilities of foreignness in emerging markets. Other research also shows similar opinions. For instance, Strike et al. (2006) suggest that secondary stakeholders (e.g., local community) tend to focus on large visible firms, which are able to generate strong impacts on their societies, and thus the behaviors of large MNE subsidiaries are often seriously monitored and criticized by them. This commentary indicates that these stakeholders draw relatively macro pictures of local societies, whereas other stakeholders, such as consumers, concerned with more direct relationships with firms, attempt to do the same job in the micro way, which sheds light on the role of consumers in particular motivating the CSR practices of SMMSs (Figure 1 confirms the interaction effects of 
local community and consumers on subsidiary CSR).

*** Insert Figure 1 about here $* * *$

In addition, a participant from the local community indicates "local communities are eager to attract foreign investment for economic benefits, such as economic stimulation and employment creation, and thus it is difficult for local communities to compel MNEs to conduct CSR”.

According to our statistical results, media is not a factor driving subsidiaries towards CSR. O'Riordan and Fairbrass (2008) point out that larger firms are likely to be more visible and thus are logically subject to more media scrutiny. In this vein, media has a propensity to frequently target large firms, which results in the latter's increasing interest in protecting its own reputation. Tixier (2003) proposes that large MNE subsidiaries need to address this new opinion risk factor by somehow handling the conduit of communication because they should not overlook the way the media manages events in local markets. Subsidiaries which violate the rules will be seriously criticized by the media, which will considerably deteriorate corporate image in the markets. However, the reason for this unexpected result, which is contradictory to existing empirical evidence, can be found simply from an explanation given by participants from the media. He says "we are not interested in small foreign subsidiaries' CSR, and try to supervise large organizations that can provide potentially striking social issues".

Unlike these factors, our result confirms findings by previous studies (e.g., Doh \& Guay, 2006; Guay et al., 2004) and points to NGOs as an important social guard putting 
strong pressure even on SMMSs in host markets. A participant from NGOs argues,

"NGOs are often referred to as the third government. Therefore, I believe subsidiaries cannot merely ignore NGO's social surveillance in local markets”.

During the focus group interviews, a consumer raised a comparable view supporting the argument above:

"Information spreads through the Internet very quickly in Korea. If an NGO reveals a foreign subsidiary's unethical behavior on a social network service, such as facebook, the subsidiary should easily be in danger in the local market. That is, an NGO's insistence will seriously and negatively influence consumer's purchase intension, which will subsequently affect corporate image. Thus, NGO's role is surely outstanding”.

\section{Managerial Relevance}

The primary idea of our argument is that relational elements (i.e., stakeholders) included in our model affect corporate decisions in terms of whether or not subsidiaries will adapt to local CSR practices. In addition, these components may significantly determine corporate behavioral patterns in local markets and subsequently function as stakeholder pressure influencing subsidiaries to act in a socially responsible manner in local societies. In other words, we expect that the extent to which subsidiaries adapt to local CSR practices and their willingness to invest in CSR issues may essentially depend on the levels of demand of the local stakeholders. In the cases where stakeholders have strong power, SMMSs need to avoid significant conflicts with them, so that the latter will improve its' organizational image, elevating corporate reputation and possibly enhancing, in turn, organizational performance in target markets. Moreover, we anticipate that it will be particularly important for SMMSs to meet 
stakeholder demands if they run businesses in emerging economies that have very different institutional business environments with the additional risk of their foreignness. Although, in theory, all stakeholders matter, in reality, the weight of each stakeholder is not identical, and thus MNE subsidiaries need to pay particular attention to influential stakeholders (Jamali, 2008). As a result, some stakeholders are highly powerful, while others have relatively limited effect on corporate ethical behaviors. In this vein, MNE managers need to carefully observe the nature of the specific market environment encountered in the host markets and try to create favorable relationships with the strong stakeholder forces rather than mere compliance to demands.

\section{Conclusions}

In this paper, we have examined determinants potentially influencing CSR practices from a stakeholder perspective. We have focused on SMMSs, as by exploring them, we believe we will be able to understand the fundamental surrounding environments of foreign firms promoting corporate citizenship and further ease and contextualize globalization for firms even when they are SMEs. Factors identified are relational determinants influencing subsidiary operations and motivating their CSR behavior in foreign markets. We may need to explain the essential rationale to draw the research framework. Although CSR issues are thoroughly dealt with in some academic areas, such as Strategic Management and Marketing, their implications for MNE subsidiaries associated with CSR have been largely overlooked in International Business research. Through both regression analyses and focus group interviews, we report three key findings: First, 'consumers', 'internal managers and employees', 
'competitors' and 'NGOs' strongly enforce SMMSs to undertake CSR activities in emerging markets. Second, in the case where local supplying firms shed light on financial growth they do not function as a social overseer for the ethical behaviors of MNE subsidiaries. Third, the role played by local community on CSR is significantly influenced by consumers.

On the theoretical side, we contribute to stakeholder theory by identifying key prime movers promoting CSR behavior and providing a short-cut to organizational triumph in the global context. As indirectly discussed above, the characteristics of the domain of international business research reside in the fact that academics and business practitioners commonly view CSR as corporate costs which has often functioned as the fuse of MNE failure in public relations. Due to the same reason, empirical examinations of MNE CSR practices still remain in its infancy. However, we argue that it is time to think about the issue of how MNEs can contribute to local economies. In this vein, our model proposes that the effects of stakeholders surrounding business settings can be an important institutional environment and they play a pivotal role in changing MNE subsidiaries' CSR practices. Our study points out that we need to explore whether proactive stakeholders' influence MNE subsidiaries' CSR practices particularly in an emerging economy context. We theoretically contribute to the general CSR literature by proposing that fulfillment of CSR practices and satisfaction to stakeholder demands can help MNEs to strengthen the market positions of their subsidiaries within their network. To sum up, we contribute to CSR literature in that we integrate relational aspects and contextualize the CSR phenomenon with MNE subsidiaries. 


\section{References}

Adam, A. M., \& Shavit, T. (2008). How can a ratings-based method for assessing corporate social responsibility (CSR) provide an incentive to firms excluded from socially responsible investment indices to invest in CSR? Journal of Business Ethics, 82, 899-905.

Arenas, D., Lozano, J. M., \& Albareda, L. (2009). The role of NGOs in CSR: Mutual perceptions among stakeholders. Journal of Business Ethics, 88, 175-197.

Avetisyan, E., \& Ferrary, M. (2013). Dynamics of Stakeholders' Implications in the Institutionalization of the CSR Field in France and in the United States. Journal of Business Ethics, 115, 115-133.

Azmat, F., \& Samaratunge, R. (2009). Responsible entrepreneurship in developing countries: Understanding the realities and complexities. Journal of Business Ethics, 90, 437-452.

Bennett, R. (1999). International business. London: Financial Times Professional Limited.

Bondy, K., Moon, J., \& Matten, D. (2012). An Institution of Corporate Social Responsibility (CSR) in Multi-National Corporations (MNCs): Form and Implications. Journal of Business Ethics, 111, 281-299.

Buckley, P. J. \& Ghauri, P. N. (2004). Globalization, economic geography and the strategy of multinational enterprises, Journal of International Business Studies, 35(2), 81-98.

Campbell, J. T., Eden, L., \& Miller, S. R. (2012). Multinationals and CSR: Does distance matter? Journal of International Business Studies, 43, 84-106.

Carroll, A. B. (1991). The Pyramid of corporate social responsibility: Toward the moral management of organizational stakeholders. Business Horizons, 34(4), 39-48.

Chang, H-J. (2004). Globalization, economic development and the role of the State. London, NY: Zed Books.

Cheng, W. L., \& Ahmad, J. (2010). Incorporating stakeholder approach in corporate social responsibility (CSR): a case study at multinational corporations (MNCs) in Penang. Social Responsibility Journal, 6(4), 593-610.

Choi, T. H., \& Nakano, C. (2008). The evolution of business ethics in Japan and Korea 
over the last decade. Human Systems Management, 27, 183-199.

Cruz, L. B., \& Boehe, D. M. (2010). How do Leading Retail MNCs Leverage CSR Globally? Insights from Brazil. Journal of Business Ethics, 91, 243-263.

Doh, J. P., \& Guay, T. R. (2006). Corporate social responsibility, public policy, and NGO activism in Europe and the United States: An institutional-stakeholder perspective. Journal of Management Studies, 43(1), 47-73.

Fornell, C., \& Larcker, D. E. (1981). Evaluating structural equation models with unobservable variables and measurement error. Journal of Marketing Research, 18(1), 39-50.

Freeman, R. E. (1984). Strategic Management: A stakeholder approach. Boston, MA: Pitman.

Freeman, R. E. (2004). The stakeholder approach revisited. Zeitschrift fuer Wirtschaftsund Unternehmensethik, 5(3), 228-241.

Gifford, B., Kestler, A., \& Anand, S. (2010). Building local legitimacy into corporate social responsibility: Gold mining firms in developing nations. Journal of World Business, 45(3), 304-311.

Godos-Díez, J-L., Fernández-Gago, R., \& Marínez-Campillo, A. (2011). How important are CEOs to CSR practices? An analysis of the mediating effect of the perceived role of ethics and social responsibility. Journal of Business Ethics, 98, 531-548.

Guay, T., Doh, J. P., \& Sinclair, G. (2004). Non-governmental organizations, shareholder activism, and socially responsible investments: Ethical, strategic, and governance implications. Journal of Business Ethics, 52, 125-139.

Ghauri, P., Elg, U. \& Tarnovskaya, V. (2008). Market driving supplier strategy: A Study of IKEA's global sourcing networks. International Marketing Review, 25(5), 504519.

Ghauri, P. \& Gronhaug, K. (2010). Research Methods in Business Studies, London: FT Pearson.

Hadjikhani, A., Lee, J-W., \& Ghauri, P. (2008). A network view of MNCs codiopolitical behavior, Journal of Business Research, 61(3), 912-924.

Hair, Jr., J. F., Anderson, R. E., \& Tatham, R. L. (1987). Multivariate data analysis. New York: McMillan.

Hair, Jr., F. J., Babin, B., Money, A. H., \& Samouel, P. (2003). Essentials of business research methods. New York: Wiley.

Han, E-K., Lee, D-H., \& Khang, H. (2008). Influential factors of the social responsibility of newspaper corporations in South Korea. Journal of Business Ethics, 82, 667-680. 
Hanke, T. \& Stark, W. (2009). Strategy development: Conceptual framework on corporate social responsibility. Journal of Business Ethics, 85, 507-516.

Husted, B. W. \& Allen, D. B. (2006). Corporate social responsibility in the multinational enterprise: Strategic and institutional approaches. Journal of International Business Studies, 37, 838-849.

Hung, H. (2011). Directors' roles in corporate social responsibility: A stakeholder perspective. Journal of Business Ethics, 103, 385-402.

Jamali, D. (2008). A stakeholder approach to corporate social responsibility: A fresh perspective into theory and practice. Journal of Business Ethics, 82, 213-231.

Kim, S. W. (2005). Utilization and practice of SPSS WIN 10.0. Seoul: Kyoyook Kwahak-Sa.

Kolk, A. \& van Tulder, R. (2010). International business, corporate social responsibility and sustainable development. International Business Review, 19, 119-125.

Korean Small and Medium Business Administration (SMBA). (2010). Scope of Korean SMEs. Seoul: SMBA.

Krueger, R. A. (1994). Focus groups: A practical guide for applied research. Thousand Oaks: Sage.

Lamberti, L. \& Lettieri, E. (2009). CSR practices and corporate strategy: Evidence from a longitudinal case study. Journal of Business Ethics, 87, 153-168.

Laudal, T. (2011). Drivers and barriers of CSR and the size and internationalization of firms. Social Responsibility Journal, 7(2), 234-256.

Lee, C-Y. \& Yoshihara, H. (1997). Business ethics of Korean and Japanese managers. Journal of Business Ethics, 16, 7-21.

Lindgreen, A., Swan, V., \& Johnson, W. J. (2009a). Corporate social responsibility: An empirical investigation of U.S. organizations. Journal of Business Ethics, 85, 303323.

Lindgreen, A., Swan, V., \& Johnson, W. J. (2009b). Corporate Social Responsibility Practices in Developing and Transitional Countries: Botswana and Malawi. Journal of Business Ethics, 90, 429-440.

Luo, Y. (2006). Political behavior, social responsibility, and perceived corruption: A structuration perspective. Journal of International Business Studies, 37, 747-766.

Lynes, J. K. \& Andrachuk, M. (2008). Motivations for corporate social and environmental responsibility: A case study of Scandinavian airlines. Journal of International Management, 14, 377-390.

Maignan, I. \& Ralston, D. A. (2002). Corporate social responsibility in Europe and the U.S.: Insights from businesses self-presentations. Journal of International Business 
Studies, 33, 497-514.

Manakkalathil, J. \& Rudolf, E. (1995). Corporate social responsibility in a globalizing market. Advanced Management Journal, 60(1), 29-47.

Maon, F., Lindgreen, A., \& Swaen, V. (2009). Designing and implementing corporate social responsibility: An integrative framework grounded in theory and practice. Journal of Business Ethics, 87, 71-89.

Mishra, S. \& Suar, D. (2010). Does corporate social responsibility influence firm performance of Indian companies? Journal of Business Ethics, 95, 571-601.

Mittal, R. K., Sinha, N., \& Singh, A. (2008). An analysis of linkage between economic valued added and corporate social responsibility. Management Decision, 46(9), $1437-1443$.

North, D. (1990). Institutions, institutional change and economic performance. Cambridge: Cambridge University Press.

O'Riordan, L. \& Fairbrass, J. (2008). Corporate social responsibility (CSR): Models and theories in stakeholder dialogue. Journal of Business Ethics, 83, 745-758.

O'Shaughnessy, K. C., Gedajlovic, E., \& Reinmoeller, P. (2007). The influence of firm, industry and network on the corporate social performance of Japanese firms. Asia Pacific Journal of Management, 24, 283-303.

OECD (2012). International trade (MEI): International trade world. [Online]. Available http://stats.oecd.org/Index.aspx?DataSetCode=MEI_TRD [accessed 8 February 2012].

Pallant, J. (2001). SPSS survival manual: A step by step guide to data analysis using SPSS for Windows. Buckingham: Open University Press.

Park, B. I. (2011). Knowledge transfer of multinational enterprises and technology acquisition in international joint ventures. International Business Review, 20, 75-87.

Park, B. I. \& Ghauri, P. N. (2011). Key factors affecting acquisition of technological capabilities from foreign acquiring firms by small and medium sized local firms. Journal of World Business, 46, 116-125.

Park, B. I. \& Choi, J. (2014). Control mechanisms of MNEs and absorption of foreign technology in cross-border acquisitions. International Business Review, 23, 130-144.

Pater, A. \& van Lierop, K. (2006). Sense and sensitivity: The roles of organization and stakeholders in managing corporate social responsibility. Business Ethics: A European Review, 15(4), 339-351.

Podsakoff, P. M., MacKenzie, S. B., Lee, J. Y., \& Podsakoff, N. P. (2003). Common method biases in behavioral research: A critical review of the literature and recommended remedies. Journal of Applied Psychology, 88(5), 879-903. 
Polonsky, M. \& Jevons, C. (2009). Global branding and strategic CSR: An overview of three types of complexity. International Marketing Review, 26(3), 327-347.

Reimann, F., Ehrgott, M., Kaufmann, L., \& Carter, C. R. (2012). Local stakeholders and local legitimacy: MNEs' social strategies in emerging economies. Journal on International Management, 18, 1-17.

Renuka, S. D. \& Ventakeshwara, B. A. (2006). A comparative study of human resource management practices and advanced technology adoption of SMEs with and without ISO certification. Singapore Management Review, 28(1), 41-61.

Rodriguez, P., Siegel, D. S., Hillman, A., \& Eden, L. (2006). Three lenses on the multinational enterprise: Politics, corruption, and corporate social responsibility. Journal of International Business Studies, 37, 733-746.

Russo, A. \& Perrini, F. (2010). Investigating stakeholder theory and social capital: CSR in large firms and SMEs. Journal of Business Ethics, 91, 207-221.

Scalet, S. \& Kelly, T. F. (2010). CSR Rating Agencies: What is Their Global Impact? Journal of Business Ethics, 94, 69-88.

Scott, W. R. (1995). Institutions and organizations. London: Sage Publications.

Tabachnick, B. G. \& Fidell, L. S. (1996). Using multivariate statistics. New York: Harper Collins.

Tixier, M. (2003). Note: Soft vs. hard approach in communicating on corporate social responsibility. Thunderbird International Business Review, 45(1), 71-91.

Torres-Baumgarten, G. \& Yucetepe, Y. (2008). Multinational firms' leadership role in corporate social responsibility in Latin America. Journal of Business Ethics, 85, 217-224.

Torugsa, N. A., O’Donohue, W., \& Hecker, R. (2012). Capabilities, Proactive CSR and Financial Performance in SMEs: Empirical Evidence from an Australian Manufacturing Industry Sector. Journal of Business Ethics, 109, 483-500.

Udayasankar, K. (2008). Corporate social responsibility and firm size. Journal of Business Ethics, 83, 167-175.

UNCTAD (2001). World investment report: Promoting linkages. Geneva: United Nations.

UNCTAD (2011). World investment report: Non-equity modes of international production and development. Geneva: United Nations.

Van Huijstee, M. \& Glasbergen, P. (2010). NGOs moving business: An analysis of contrasting strategies. Business \& Society, 49(4), 591-618.

Vilanova, M., Lozano, J. M., \& Arenas, D. (2008). Exploring the nature of the relationship between CSR and competitiveness. Journal of Business Ethics, 87, 57- 
69.

Waddock, S. A. \& Graves, S. B. (1997). The Corporate Social Performance - Financial Performance Link. Strategic Management Journal, 18(4), 303-320.

Waldman, D. A., de Luque, M. S., Washburn, N., \& House, R. J. (2006). Cultural and leadership predictors of corporate social responsibility values of top management: A GLOBE study of 15 countries. Journal of International Business Studies, 37, 823837.

Worthington, I., Ram, M., \& Jones, T. (2006). Exploring corporate social responsibility in the U.K. Asian small business community. Journal of Business Ethics, 67, 201217.

Yang, X. \& Rivers, C. (2009). Antecedents of CSR practices in MNCs'subsidiaries: a stakeholder and institutional perspective. Journal of Business Ethics, 86, 155-169.

Ziegler, J. (2005). L'empire de la honte. Paris: Fayard. 
Table 1. Descriptive statistics and correlations

\begin{tabular}{|c|c|c|c|c|c|c|c|c|c|c|c|c|c|c|}
\hline & Mean & S.D. & 1 & 2 & 3 & 4 & 5 & 6 & 7 & 8 & 9 & 10 & 11 & 12 \\
\hline $\begin{array}{l}\text { 1. Development status of } \\
\text { MNE origin }\end{array}$ & 0.58 & 0.50 & 1.00 & & & & & & & & & & & \\
\hline 2. Ownership structure & 64.66 & 36.48 & $-0.28^{* *}$ & 1.00 & & & & & & & & & & \\
\hline 3. Institutional distance & 1.99 & 1.17 & 0.02 & 0.02 & 1.00 & & & & & & & & & \\
\hline 3. Subsidiary size & 47.06 & 55.75 & $0.26^{* *}$ & $0.23^{* *}$ & 0.02 & 1.00 & & & & & & & & \\
\hline 4. Subsidiary age & 9.37 & 8.76 & $0.32^{* * *}$ & -0.03 & $0.15^{* *}$ & $0.12^{*}$ & 1.00 & & & & & & & \\
\hline 5. Consumer & 3.11 & 0.70 & -0.04 & -0.09 & $-0.14^{*}$ & -0.05 & $-0.12^{*}$ & 1.00 & & & & & & \\
\hline $\begin{array}{l}\text { 6. Internal managers and } \\
\text { employees }\end{array}$ & 3.24 & 0.74 & 0.11 & -0.11 & $-0.32^{* * *}$ & -0.10 & -0.08 & $0.57^{* *}$ & 1.00 & & & & & \\
\hline 7. Government & 2.57 & 1.36 & 0.05 & 0.02 & $0.30^{* *}$ & -0.02 & $0.20^{* * *}$ & $-0.15^{* *}$ & $-0.19^{* *}$ & 1.00 & & & & \\
\hline 8. Suppliers & 3.39 & 0.61 & 0.03 & -0.03 & 0.00 & -0.01 & -0.00 & $0.26^{* *}$ & $0.36^{* *}$ & 0.02 & 1.00 & & & \\
\hline 9. Investors & 2.93 & 0.86 & -0.03 & -0.01 & $-0.18^{* * *}$ & -0.11 & -0.07 & $0.42^{* *}$ & $0.35^{* *}$ & -0.03 & 0.03 & 1.00 & & \\
\hline 10. Competitors & 3.23 & 0.56 & -0.03 & 0.04 & -0.09 & -0.00 & -0.01 & 0.05 & 0.04 & $-0.12^{*}$ & -0.01 & -0.03 & 1.00 & \\
\hline 11. Media & 3.46 & 0.62 & -0.06 & -0.05 & -0.11 & 0.01 & $-0.12^{*}$ & $0.30^{* *}$ & $0.16^{* *}$ & -0.05 & $0.28^{* *}$ & 0.06 & 0.07 & 1.00 \\
\hline 12. Local community & 3.33 & 0.77 & -0.02 & -0.03 & $-0.35^{* *}$ & 0.04 & $-0.14^{*}$ & $0.59^{* *}$ & $0.64^{* *}$ & $-0.22^{* *}$ & $0.29^{* *}$ & $0.43^{* *}$ & 0.06 & $0.26^{* * *}$ \\
\hline 13. NGO & 2.94 & 0.71 & $-0.15^{*}$ & $0.14^{*}$ & $-0.20^{* * *}$ & $-0.15^{*}$ & $-0.15^{* *}$ & $0.24^{* *}$ & $0.25^{* *}$ & -0.10 & 0.08 & $0.28^{* *}$ & 0.02 & $0.32^{* *}$ \\
\hline 14. CSR & 3.47 & 0.67 & -0.02 & 0.01 & $-0.35^{* *}$ & -0.10 & $-0.18^{* * *}$ & $0.56^{* *}$ & $0.56^{* *}$ & $-0.19^{* *}$ & 0.07 & $0.33^{* *}$ & $0.22^{* *}$ & $0.25^{* *}$ \\
\hline
\end{tabular}

(Continued) 
Table 1. Descriptive statistics and correlations (continued).

\begin{tabular}{lllll}
\hline & Mean & S.D. & 13 & 14 \\
\cline { 1 - 3 } $\begin{array}{l}\text { 1. Development status of } \\
\quad\end{array}$ & 0.58 & 0.50 & & \\
2. Ownership structure & 64.66 & 36.48 & & \\
3. Institutional distance & & & & \\
3. Subsidiary size & 47.06 & 55.75 & & \\
4. Subsidiary age & 9.37 & 8.76 & & \\
5. Consumer & 3.11 & 0.70 & & \\
6. Internal managers and & 3.24 & 0.74 & & \\
$\quad$ employees & & & & \\
7. Government & 2.57 & 1.36 & & \\
8. Suppliers & 3.39 & 0.61 & & \\
9. Investors & 2.93 & 0.86 & & \\
10. Competitors & 3.23 & 0.56 & & \\
11. Media & 3.46 & 0.62 & & \\
12. Local community & 3.33 & 0.77 & 1.00 & \\
13. NGO & 2.94 & 0.71 & $0.39^{* *}$ & 1.00 \\
14. CSR & 3.47 & 0.67 & $0.59^{* *}$ & $0.46^{* *}$ \\
\hline
\end{tabular}

Notes: $\mathrm{N}=291 ;{ }^{* *} \mathrm{p}<0.01 ;{ }^{*} \mathrm{p}<0.05$; AVE values are consumer (0.643), 'internal managers and employees' (0.653), government (0.591), suppliers (0.507), investors (0.563), competitors (0.543), media (0.616), local community (0.630), NGO (0.621) and CSR (0.629), respectively 
Table 2. Analysis results: OLS regression

\begin{tabular}{|c|c|c|c|c|c|}
\hline & Model 1 & Model 2 & Model 3 & Model 4 & VIF \\
\hline Development status of MNE origin & 0.011 & 0.043 & 0.029 & 0.035 & 1.265 \\
\hline Ownership structure & 0.050 & -0.039 & -0.004 & 0.000 & 1.213 \\
\hline Institutional distance & $-0.166^{* *}$ & -0.073 & $-0.098^{*}$ & $-0.107^{*}$ & 1.318 \\
\hline Subsidiary size & -0.022 & -0.053 & -0.018 & -0.019 & 1.248 \\
\hline Subsidiary age & $-0.100^{*}$ & -0.066 & -0.071 & -0.025 & 1.229 \\
\hline Consumers & $0.410^{* * *}$ & & $0.337^{* * *}$ & $0.274^{* * *}$ & 2.108 \\
\hline Internal managers and employees & $0.320^{* * *}$ & & $0.282^{* * *}$ & & 3.297 \\
\hline Governments & 0.055 & & 0.038 & & 1.181 \\
\hline Suppliers & $-0.139^{* *}$ & & $-0.154^{* *}$ & & 1.305 \\
\hline Investors & 0.070 & & 0.020 & & 1.479 \\
\hline Competitors & & $0.131^{* * *}$ & $0.109^{*}$ & $0.091^{*}$ & 1.031 \\
\hline Media & & 0.040 & 0.027 & 0.043 & 1.362 \\
\hline Local community & & $0.448^{* * *}$ & 0.059 & $0.161^{* *}$ & 3.524 \\
\hline NGOs & & $0.287^{* * *}$ & $0.280^{* * *}$ & $0.163^{* *}$ & 1.375 \\
\hline Customer X Local community & & & & $-0.333^{* * *}$ & \\
\hline Adjusted $\mathrm{R}^{2}$ & 0.517 & 0.477 & 0.597 & 0.627 & \\
\hline $\mathrm{F}$ & $25.843^{* * *}$ & $24.499^{* * *}$ & $25.535^{* * *}$ & $36.445^{* * *}$ & \\
\hline
\end{tabular}


Figure 1. A graphical representation of moderating effects: Interaction effects of local community and consumers on subsidiary CSR

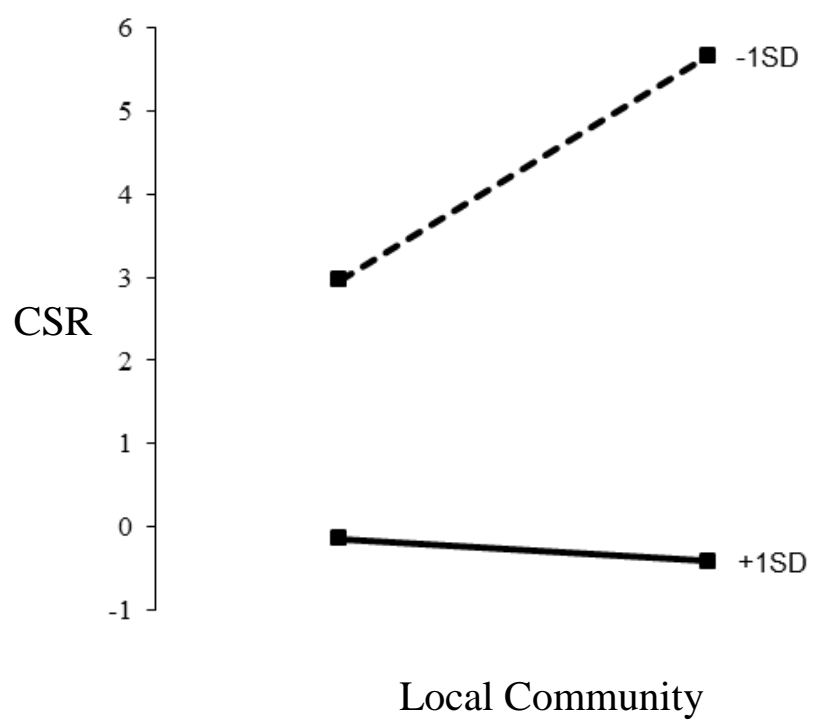




\section{Appendix A. Variable measurements}

1. Dependent variable (MNE CSR: adopted from Luo, 2006)

Items (ranging from $1=$ very strongly disagree to 5 = very strongly

Cronbach's

agree)

alpha

(1) Our company has established a set of transparent, comprehensive,

0.925

and stringent codes of conduct aiming at resisting bribery, corruption, and other illicit acts in the host country. (2) Throughout the company, every manager and employee has strictly implemented the above codes of conduct. (3) Our company has established an ethics compliance department or division that specifically handles the improvement, training, and enforcement of the above codes of conduct. (4) Our company always attaches the utmost value to, and takes actual steps in, enhancing corporate image and reputation. (5) Our company always honors our promises regarding product and/or service offerings and is dedicated to adapt to the local consumers' needs. (6) Relying on its honesty and credibility, our company has maintained good and stable relationships with local suppliers, distributors, and other business partners. (7) Each year our company allocates some portion of retained earnings to charitable organizations. (8) Our company always recognizes its social responsibility and participates in helping the needy and the outcasts of society and improving a backward facility of the local community. (9) Each year our company uses some portion of retained earnings to help the local community to consummate the public infrastructure and environmental protection. (10) The resources (e.g., technology, skills, capital, or equipment) we invested in local project(s) are always complementary to the host country's economic development needs. (11) We always invest resources (e.g., technology, skills, capital, or equipment) that the local government needs for social development. (12) The resources (e.g., technology, skills, capital, or equipment) we invested in local project(s) always contribute to industrial development by enhancing technological and managerial knowledge in the local market. 


\section{Appendix A (continued).}

\section{Independent variables}

\begin{tabular}{|c|c|c|}
\hline Variable & $\begin{array}{l}\text { Measurement (ranging from } 1=\text { very strongly } \\
\text { disagree to } 5 \text { = very strongly agree) }\end{array}$ & $\begin{array}{l}\text { Cronbach's } \\
\text { alpha }\end{array}$ \\
\hline $\begin{array}{l}\text { Consumer } \\
\text { (Adapted from Tian, } \\
\text { Wang \& Yang, 2011) }\end{array}$ & $\begin{array}{l}\text { (1) Consumers care about environmental } \\
\text { protection in the daily consumption. (2) } \\
\text { Consumers pay attention to some social issues } \\
\text { involving firm's charitable donations. (3) } \\
\text { Consumers tend to buy those products which } \\
\text { are produced by firms that are socially } \\
\text { responsible rather than goods which are fine } \\
\text { and inexpensive. }\end{array}$ & 0.907 \\
\hline $\begin{array}{l}\text { Internal managers and } \\
\text { employees } \\
\text { (Adapted from Munilla } \\
\text { \& Miles, 2005) }\end{array}$ & $\begin{array}{l}\text { (1) Our managers and employees perceive } \\
\text { CSR as an important mechanism potentially } \\
\text { contributing to the creation of corporate } \\
\text { value. (2) Our managers and employees } \\
\text { perceive that CSR enhances competitive } \\
\text { advantage, and eventually improves the } \\
\text { economic value of the firm. (3) Our managers } \\
\text { and employees believe firms need to } \\
\text { contribute to local countries, societies and } \\
\text { markets. (4) Our managers and employees } \\
\text { believe being ethical and socially responsible } \\
\text { is the most important thing a firm should do. }\end{array}$ & 0.743 \\
\hline $\begin{array}{l}\text { Governments } \\
\text { (Adapted from Qu, } \\
\text { 2007) }\end{array}$ & $\begin{array}{l}\text { (1) The local government has stricter } \\
\text { regulations to protect the consumers. (2) The } \\
\text { local government has effective regulations to } \\
\text { encourage firms to improve their product and } \\
\text { services quality. (3) There are complete laws } \\
\text { and regulations to ensure fair competition. }\end{array}$ & 0.943 \\
\hline $\begin{array}{l}\text { Suppliers } \\
\text { (Created by this study) }\end{array}$ & $\begin{array}{l}\text { (1) Local suppliers tend to prefer close } \\
\text { cooperation with firms which are socially } \\
\text { responsible. (2) Local suppliers tend to prefer } \\
\text { the maintenance of cooperation with firms } \\
\text { which are socially responsible. (3) Local } \\
\text { suppliers have a propensity to apply social } \\
\text { and environmental requirements to their } \\
\text { business relationships. }\end{array}$ & 0.831 \\
\hline
\end{tabular}

(Continued) 


\section{Appendix A (continued).}

\begin{tabular}{|c|c|c|}
\hline Variable & $\begin{array}{l}\text { Measurement (ranging from } 1=\text { very strongly } \\
\text { disagree to } 5=\text { very strongly agree) }\end{array}$ & $\begin{array}{c}\text { Cronbach's } \\
\text { alpha }\end{array}$ \\
\hline $\begin{array}{l}\text { Investors } \\
\text { (Created by this study) }\end{array}$ & $\begin{array}{l}\text { (1) Investors tend to prefer investment into } \\
\text { firms which are socially responsible. (2) } \\
\text { Investors expect firms to implement various } \\
\text { and active CSR practices in host country. (3) } \\
\text { Investors actively indicate and support firms' } \\
\text { CSR practices. }\end{array}$ & 0.908 \\
\hline $\begin{array}{l}\text { Competitors } \\
\text { (Adapted from } \\
\text { Lindgreen et al., } \\
\text { 2009b) }\end{array}$ & $\begin{array}{l}\text { Due to local business environment, firms } \\
\text { suffer from pressure on emulating } \\
\text { competitors' 1) social, 2) environmental, and } \\
\text { 3) ethical policies and practices. }\end{array}$ & 0.668 \\
\hline $\begin{array}{l}\text { Media } \\
\text { (Created by this study) }\end{array}$ & $\begin{array}{l}\text { (1) Media plays a pivotal role in maintaining } \\
\text { and improving public relations between firms } \\
\text { and consumers in the local market. (2) Mass } \\
\text { media has a strong power in shaping corporate } \\
\text { image and reputation in the local market. ( } 3 \text { ) } \\
\text { Compared with other countries, mass media in } \\
\text { Korea pays more attention to the societal role } \\
\text { of firms in the local market. }\end{array}$ & 0.818 \\
\hline $\begin{array}{l}\text { Local community } \\
\text { (Created by this study) }\end{array}$ & $\begin{array}{l}\text { (1) Local communities expect companies to } \\
\text { contribute to society development by } \\
\text { volunteering time and effort to local activities. } \\
\text { (2) Local communities expect companies to } \\
\text { contribute to society development by getting } \\
\text { involved in community event in non-financial } \\
\text { ways. (3) Local communities expect } \\
\text { companies to contribute to society } \\
\text { development by providing jobs and treating } \\
\text { their employees well. }\end{array}$ & 0.925 \\
\hline
\end{tabular}




\section{Appendix A (continued).}

\begin{tabular}{|l|l|c|}
\hline Variable & $\begin{array}{l}\text { Measurement (ranging from 1 = very } \\
\text { strongly disagree to 5 = very strongly } \\
\text { agree) }\end{array}$ & $\begin{array}{c}\text { Cronbach's } \\
\text { alpha }\end{array}$ \\
\hline $\begin{array}{l}\text { NGOs } \\
\text { (Created by this study) }\end{array}$ & $\begin{array}{l}\text { (1) NGOs police and supervise } \\
\text { effectively corporate activities in the } \\
\text { local market. (2) NGOs have a } \\
\text { propensity to attempt to influence the } \\
\text { CSR activities of corporate } \\
\text { management by using various } \\
\text { instruments. (3) NGO community in } \\
\text { the local market has a sufficient power } \\
\text { to exert pressure on multinational } \\
\text { enterprises to change their behavior } \\
\text { and corporate strategy on CSR } \\
\text { activities. }\end{array}$ \\
\hline
\end{tabular}

